\title{
De livsviktige pårørende
}

\section{Når man blir pårørende til alvorlig syke pasienter, er eget matinntak noe av det siste man tenker på.}

18. januar 2013 er en dato jeg aldri glemmer. Denne dagen ble jeg en pårørende. Uten forvarsel fikk lillesøsteren min på 17 år hjerneblødning. Et ungt og friskt menneske lå plutselig livløst foran meg i sykehussengen. Sykepleierne og legene jobbet hardt for å holde henne i live. Jeg satt og så på dette mennesket som jeg hadde kjent så godt. Det var som om det var en fremmed som lå der. Hvor var lillesøsteren min?

De neste ukene holdt jeg henne i hånden. Det var det jeg kunne gjøre. Holde henne, som for å holde fast i det livet som var der inne et sted. Jeg var sulten og trøtt. Men mine behov ble så små når jeg så på søsteren min som kjempet for å få leve. Hvorfor skulle jeg si til sykepleierne, som kjempet med min søster, at jeg var sulten. Nei, det kunne jeg ikke. Jeg ble sittende og holde henne i hånden. I ukene mens jeg satt der forsvant 10 kilo av meg. Jeg ble altfor tynn, men fortsatt virket det urettferdig å si høyt at jeg trengte mat. Men er det ikke mat å få kjøpt på sykehuset, har noen lurt på i ettertid. Jo, men det krevde at jeg måtte reise meg fra stolen ved sykehussengen, slippe taket i hånden til lillesøsteren min og gå ned i en kiosk som er preget av glede. Der satt nybakte foreldre og gledet seg over livets under, mens jeg bar på en sorg så stor at den ikke fikk plass i den lille kiosken. Det var ikke plass til meg. Og ikke var lommeboken min særlig glad for den dyre maten heller.

Men mens jeg satt der og holdt søsteren min, kom en venn med mat ved et par anledninger. Dette var en gest som var godt både for mage og sjel. Maten mettet, og den fortalte meg at vi ble sett. Den var ikke nok til å mette hver dag, men den mettet noe av behovet etter omsorg. Mange tenkte at det beste var å ikke forstyrre meg og min familie når vi hadde det som verst. Men dere, alltid forstyrr. Ikke ved å stille krav eller spørsmål, men det å si at du bryr deg, betyr alltid noe.

Maten vi fikk glemte jeg aldri. Da et år hadde gått, ønsket jeg å takke sykepleierne og legene for den jobben de gjorde. De så oss, de hørte på oss, de svarte på alle våre spørsmål, de pleiet min søster med verdighet og omsorg. De fortjener mer ros enn jeg noen gang kan gi. Etter et år hadde jeg kommet meg litt til hektene igjen. Både kroppen og psyken begynte å finne tilbake til seg selv. Tiden var inne for å si takk. Men hvordan? Da kom jeg på den vennlige gesten med mat. Dette ønsket jeg å videreføre. Dette kan jeg også gjøre - selv om jeg ikke kjenner de pårørende. Med denne tanken startet jeg «Ventemat». To ganger i uken er jeg, eller en av de andre frivillige, innom Rikshospitalet med mat til de pårørende på intensivavdelingen. Vi er i dag en gruppe på 13 som baker og leverer mat. Vi ønsker å bidra med mat som gjerne er sunn og god. Leveringen av mat skjer etter avtale med sykehuset etter retningslinjer vi har fått av dem. På hvert pårørenderom står det en kurv som vi fyller med bakst, frukt og pålegg. Jeg kan ikke mette de pårørende hver dag. Men jeg kan bidra med noe. Jeg kan bidra med mat to ganger i uken. Og hvem vet, kanskje det en gang kan bli oftere? Jeg håper Ventemat kan fortelle de ansatte at jeg er takknemlig for jobben de gjør, jeg håper Ventemat kan si til de pårørende at noen heier på dem, og jeg håper Ventemat også kan formidle et budskap utenfor sykehusets vegger om en gruppe som fort blir gjemt og glemt.

Og du lurer kanskje på hvordan det har gått med søsteren min? Jeg har sluppet hånden hennes. Hun har reist seg fra sengen. Men hun har fortalt meg at hånden som holdt var livsviktig. «Det var bare når dere holdt meg i hånden at jeg visste at jeg levde», har hun sagt. Pårørendehånden er viktig for pasienten. La oss ta godt vare på pårørende som sitter ved sykehussenger og holder i hender.

Den omtalte har gitt samtykke til at artikkelen blir publisert.

\section{Ester-Marie Fiskum}

